\title{
Control of Exhaust Emissions in Four Stroke Compression Ignition Engine by Using Piston Coatings with Diesel Blends
}

\author{
A.V.N.S. Kiran*, Sadu Venkatesu and N. Venkatachalapathi \\ Department of Mechanical Engineering, Anamacharya Institute of Technology and Science, New Boyanapalli, \\ Kadapa District, Andhra Pradesh, India.
}

\begin{abstract}
The experimental investigations on four stroke single cylinder compression ignition engine is to reduce the exhaust emissions by using unleaded diesel and alcohol blends on the CI engine with $25 \%$ ethanol, $25 \%$ beutanol, $25 \%$ proponol and $75 \%$ diesel used to control carbon mono oxide (CO) and UN burnt hydro carbons (UBHC)\& Nitrous Oxide (NOx). These pollutants are hazardous to the nature and cause health problems to the human beings and impact on the environment. The copper coated piston (CCP) of $300 \mu$ of thickness is coated on the piston crown. A micro processor based analyzer is used for the measurement of $\mathrm{CO}$, NOX and UBHC from the exhaust manifold. The work done on the CI engine is fuelled with ethanol, beutanol and propanol blends of proportions are compared with the base piston (BP), CCP engine, to find the performance (break thermal efficiency, specific fuel consumption etc..,) and emission characteristics. The CCP with alcohol blended diesel is considerably reduces emissions of CO, NOx and UBHC and increase in the engine performance characteristics when compared to the BP with pure diesel operation.
\end{abstract}

Keywords: BP : Base Piston, CCP: Copper Coated Piston, Set-1: 25\% Ethanol+75\% Diesel Set2: $25 \%$ Beutanol+ 75\% Diesel, Set3: 25\% Proponol+ 75\% Diesel

\section{Introduction}

Combustion is a chemical reaction in which certain elements of fuel like hydrogen and carbon combined with oxygen liberating the heat energy causing an increase in temperature of the gases the conditions necessary for the combustion are the presence of combustible mixture and some means of initiating the process. The combustion is a very complex subject and has been a topic of intensive research for many years. The work is carried out to find out the combustion characteristics on different piston combustion chambers. In an internal combustion engines, the piston is one of the one of the most important and complex part, hence it is most important to maintain piston is good condition in order to main the proper functioning of the engine. The 4 stroke compression ignition engines are releasing of more quantity of nitrous oxide, UN burnt hydrocarbons and carbon mono oxide. In order to reduce these pollutants lot of research works are done by using the piston coatings and adding the diesel blends. Fuel consumption etc.,) and emission characteristics and results are compared to both base piston (BP) and copper coated piston (CCP). All these years there have always been some IC engines fuelled with non- gasoline and diesel oil fuels. However their numbers have been relatively small. Because of the high cost of petroleum products, some developing countries are trying to use alternate fuels of their vehicles.

The engines used for an alternative fuels are used modified engines which were originally designed for gasoline fuelling. During extensive research and development in done over a period of years, maximum performance and efficiency can be realized from these engines. However the research and development is not easy to justify until the fuels are accepted as variable for large numbers of engine.

The engines run with the gasoline, the emissions from $\mathrm{CI}$ engine \& their formation of $\mathrm{CO}, \mathrm{NOx}$ and the UBHC are released from the exhaust manifold.CO, NOx and UBHC are major exhaust emissions formed due to incomplete combustion of fuel, cause many human health disorders. Such emissions also cause detrimental effects on animal and plant life, besides environmental disorders. Age and maintenance of the vehicle are some of the reasons for the formation of pollutants. Aldehydes are intermediate compounds formed in combustion are carcinogenic in nature and cause detrimental effects on human health. So control of these pollutants is an immediate task. Engine modification with copper coating on piston crown to improve engine performance, as the copper is a good conductor of heat and combustion improved it is reported that the catalyst improved the fuel economy and increased combustion stabilization.

Alcohol blended with gasoline to reduce pollutants and improve the performance. CO NOx and UBHC emissions are reduced with blendes of alcohol with diesel. The present paper reports the performance evaluation of CCP with alcohol blended diesel 


\subsection{Statement of the problem:}

As the four stroke engines use different types of fuels like petrol, diesel, gas etc. In current days the use of four stroke diesel engines are releasing the emissions of harm full gasses and maximum fuel consumption. To overcome these difficulties, the CCP is placed instead of BP and also using the different diesel additive blends to reduce the harmful emissions.

\subsection{Objective of the study:}

The objective of this study is to analyze the performance of the four stroke diesel engine using ethanol, beutanol and proponol as an additive with the diesel. So as to overcome the above stated difficulties.

\subsection{Scope of the study:}

To increase the performance of the four stroke diesel engine, the ethanol, beutanol and proponol is used as an additive with diesel. The readings obtained from the conducted tests have been evaluated and the results and graphs are compared with both the CCP and BP.

\section{Literature Survey}

S. Narasimha Kumar [1]: The concept of catalytic combustion in spark ignition engines has been tried by various researches which offers improved thermal efficiency and reduced exhaust emissions due to oxidation of fuels with aid of catalyst. The piston top and cylinder head are coated with catalytic materials such as copper, chromium and nickel using flame spray gun. The performance, emission and combustion characteristics of the engine coated with catalytic materials are studied and are compared with the standard engine. In the present paper experimental investigations were conducted to evaluate the performance and control the exhaust emissions from two-stroke, single cylinder, spark ignition (SI) engine, with alcohol blended gasoline $(80 \%$ gasoline and $20 \%$ ethanol by volume) provided with catalytic converter with sponge iron as catalyst and compared with conventional SI engine (CE) with pure gasoline operation. Performance parameters (brake thermal efficiency, exhaust gas temperature and volumetric efficiency) and exhaust emissions (carbon monoxide (CO) and un-burnt hydro carbons (UBHC)) were determined with different values of brake mean effective pressure of the engine. A microprocessor-based analyzer was used for the measurement of CO/UBHC in the exhaust of the engine. Copper coated combustion chamber with alcohol blended gasoline considerably improved the performance and reduced pollutants in comparison with CE with pure gasoline operation. Catalytic converter with air injection significantly reduced pollutants with test fuels on both configurations of the combustion chamber. The catalyst, sponge reduced the pollutants effectively with both test fuels in both versions of the combustion chamber.

Narasimha Kumar.S , Murali Krishna M.V.S. Murthy P.V.K., Reddy D.N., Kishor K [2]: Investigations are conducted on two stroke, single cylinder spark ignition (SI) engine with gasohol (80\% gasoline, $20 \%$ ethanol, by vol) having copper coated engine [CCE, copper( thickness, $300 \mu$ ) coated on piston crown, inner side of liner and cylinder head provided with catalytic converter with different catalysts such as sponge iron and manganese ore and compared with conventional SI engine (CE) with gasoline operation. Brake thermal efficiency and volumetric efficiency increased with gasohol with both versions of the engine. CCE showed improved performance and decreased pollution levels when compared to CE with both test fuels. Catalytic converter with air injection significantly reduced pollutants with both test fuels on both configurations of the engine. The catalyst, sponge iron reduced emissions effectively when compared with manganese ore in both versions of the engine with both test fuels.

T.O. Wagner, D.S. Gray, B.Y. Zarah, A.A. Kozinski [3]: Alcohols have been suggested as an engine fuel almost since automobile was invented. The alcohol used to change/modify the attitude towards the present fuel, i.e., gasoline and Search for new alternatives. The first approach was selected with the aim of improving the combustion Characteristics of gasoline, which will be reflected in improving the engine performance and that is done by mixing methanol, ethanol. This paper investigates the performance parameters like brake thermal efficiency, volumetric efficiency, brake specific fuel consumption and emission characteristics like NOX, $\mathrm{UBHC}, \mathrm{CO}$ etc.

Viral K Pandya, Shailesh N Chaudhary, Bakul T Patel, Parth D Patel [4]: This experimental study investigates the effect of using unleaded gasoline and alcohol as additives blends on spark ignition engine (SI engine) performance. Two strokes, single cylinder SI engine were used for conducting this study. Performance tests were conducted for fuel consumption, brake thermal efficiency, brake power, engine power, indicated thermal efficiency and brake specific fuel consumption using unleaded gasoline and additives blends with different percentages of alcohol at varying engine load condition and at constant engine speed. The result showed that blending unleaded gasoline with additives increases the brake power, indicated and brake thermal 
efficiencies, fuel consumption and mechanical efficiency. The addition of 5\% methanol, 5\% ethanol and 5\%nbutanol to gasoline gave the best results for all measured parameters at all engine torque/power values.

\subsection{Load Vs BSFC:}

\section{Results \& Discussions}

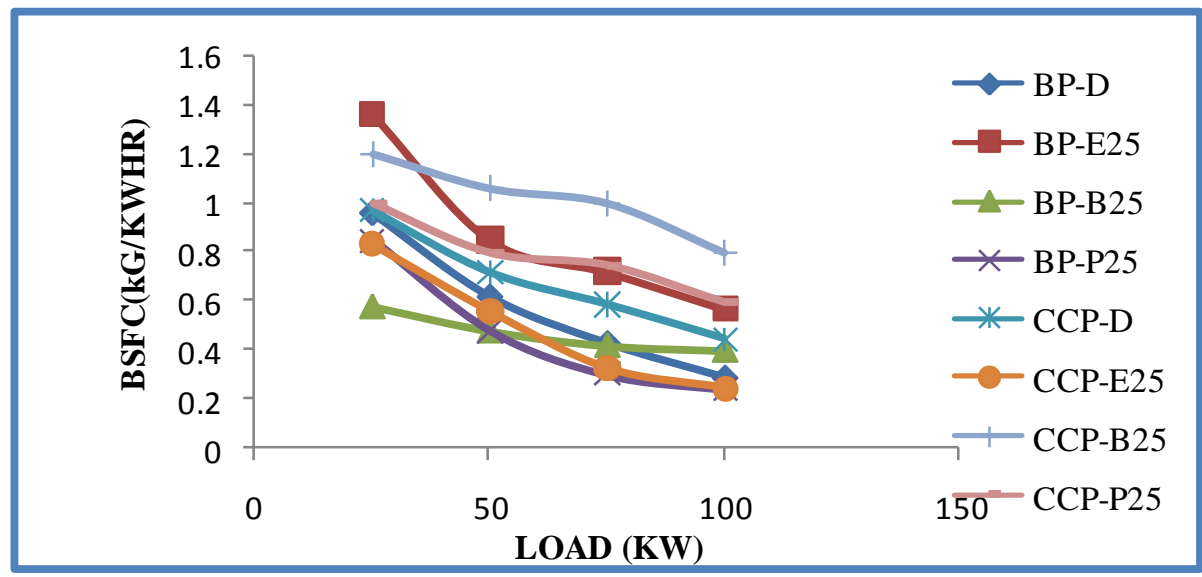

Fig.1. Load Vs BSFC

\section{Specific Fuel Consumption:}

From the Fig.1 refers the effect of using ethanol, beutanol and proponol diesel blends on Brake Specific Fuel Consumption (BSFC) is shown in the load vs. BSFC graphs. From the graphs SFC decreases as the engine torque increases.

From the graphs by using ethanol and methanol on BP and CCP with the proportions of $25 \%$ diesel, the gradual decreasing of the specific fuel consumption when comparing to the BP and CCP the overall fuel consumption is decreased by $10-12 \%$ to the CCP than the BP with the $25 \%$ of beutanol blend.

\subsection{Load Vs Break Thermal Efficiency:}

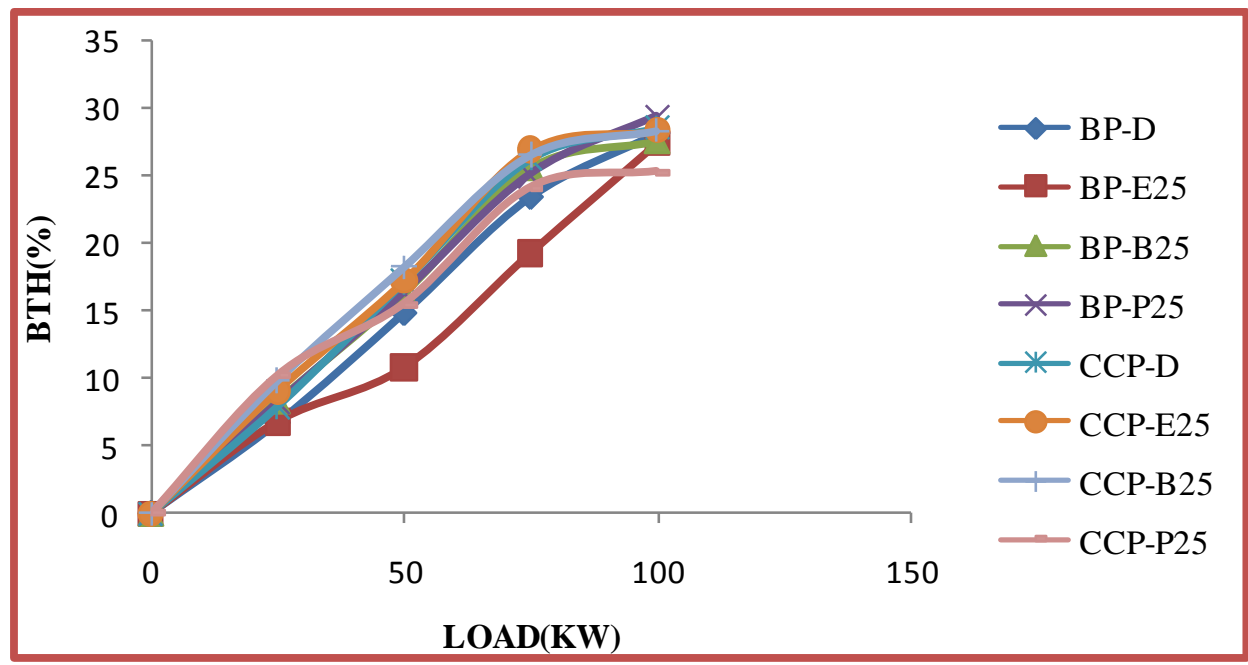

Fig.2. Load Vs BTH

Brake Thermal Efficiency:

From the Fig.2 refers the effect of using the ethanol, beutanol, and propanol on diesel blends on brake thermal efficiency is shown in the load vs. brake thermal efficiency. As shown from the graphs the brake thermal efficiency increases by using the ethanol and beutanol. The overall brake thermal efficiency is increased by $1.02 \%$ when comparing the BP to CCP with the blends of ethanol, beutanol and propanol with diesel. 


\subsection{Load vs Hydro Carbon}

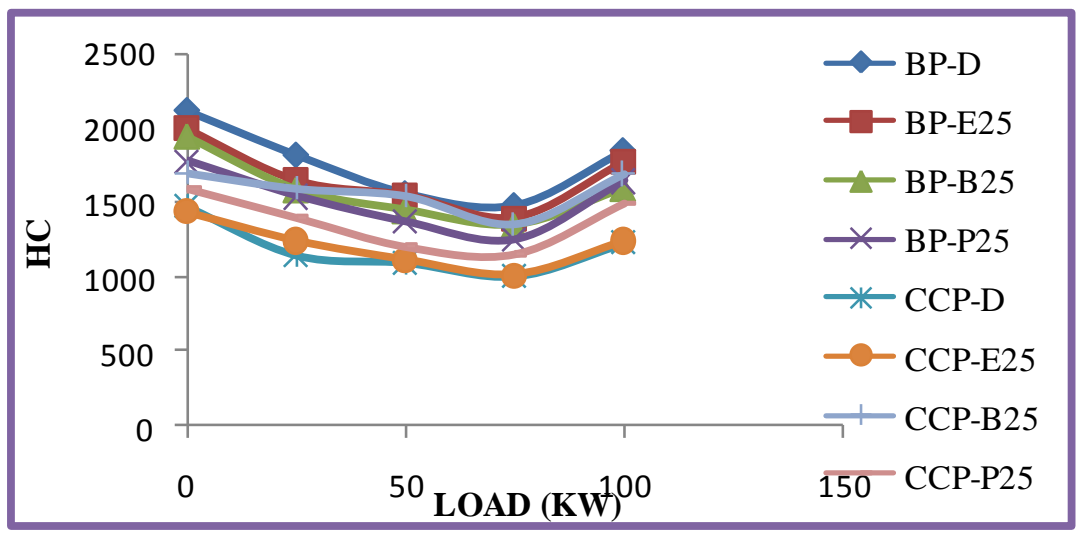

Fig.3. Load Vs HC

\section{UN burnt hydrocarbon emissions:}

From the Fig.3 refers the measured unburned hydro carbon emissions for BP and CCP with the blends of ethanol beutanol and propanol blends are shown in the figures load Vs HC emissions. By using the ethanol beutanol and propanol blends of $25 \%$ proportions, these results in the decrease of the UBHC emissions of CCP when compared to BP. Due to mixing of blends, at high temperatures, Engine will have sufficient amount of oxygen, which mixes with $\mathrm{HC}$ emissions. As a result $\mathrm{HC}$ will split in to $\mathrm{H}$ and $\mathrm{C}$ which mixes with $\mathrm{O}_{2}$ thereby reducing the $\mathrm{HC}$ emissions.

When comparing with the BP and CCP with the emissions are reduced up to $28 \%-30 \%$.

\subsection{Load Vs CO:}

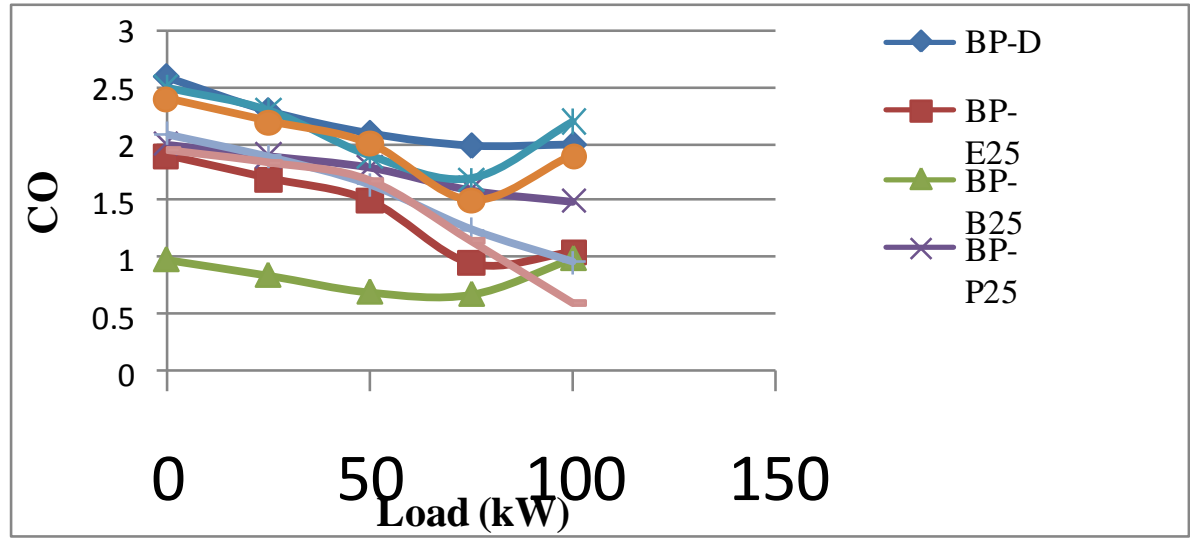

\section{Load Vs CO}

\section{Carbon Monoxide (CO) Emissions:}

From the Fig.4 refers emissions of $\mathrm{CO}$ for various loads, it is found that the $\mathrm{CO}$ emissions are decreased in CCP with $25 \%$ of ethanol blend, when compared to the BP due to complete combustion. At high temperature $\mathrm{C}$ easily combines with $\mathrm{O} 2$ and reduces $\mathrm{CO}$ emission. This results in the reduction of the $\mathrm{CO}$ emissions up to $23 \%-25 \%$, when compared to the BP and CCP of blend ethanol $25 \%$.

\section{Conclusion}

The experimental study is to control the exhaust emissions from the four stroke single cylinder compression ignition engine using unleaded diesel and alcohol blends on the CI engine with $25 \%$ ethanol, $25 \%$ beutanol, $25 \%$ proponol and $75 \%$ diesel used to control carbon mono oxide (CO) and UN burnt hydro carbons (UBHC)\& Nitrous Oxide (NOx). These pollutants are hazardous to the nature and cause health problems to the human beings and impact on the environment. The copper coated piston (CCP) of $300 \mu$ of thickness is coated on the piston crown. A micro processor based analyzer is used for the measurement of CO, NOx and UBHC from the exhaust manifold. The work done on the CI engine is fuelled with ethanol, beutanol and propanol blends of proportions are compared with the base piston (BP), CCP engine, to find the performance (break thermal efficiency, specific fuel consumption etc..,) and emission characteristics. The CCP with alcohol 
blended diesel is considerably reduces emissions of CO, NOx and UBHC and increase in the engine performance characteristics when compared to the BP with pure diesel operation.

\section{The following results are discussed below:}

$>\quad$ The effect of using ethanol, beutanol and proponol diesel blends on brake specific fuel consumption (BSFC) is shown in the load vs. bsfe graphs. From the graphs SFC decreases as the engine torque increases. From the graphs by using ethanol and methanol on BP and CCP with the proportions of $25 \%$ diesel, the gradual decreasing of the specific fuel consumption when comparing to the BP and CCP the overall fuel consumption is decreased by $10-12 \%$ to the CCP than the BP with the $25 \%$ of beutanol blend.

$>\quad$ The effect of using the ethanol, beutanol, and propanol on diesel blends on brake thermal efficiency is shown in the load vs. brake thermal efficiency. As shown from the graphs the brake thermal efficiency increases by using the ethanol and beutanol. The overall brake thermal efficiency is increased by $1.02 \%$ when comparing the BP to CCP with the blends of ethanol, beutanol and propanol with diesel.

$>\quad$ The measured unburned hydro carbon emissions for BP and CCP with the blends of ethanol beutanol and propanol blends are shown in the figures load Vs HC emissions. By using the ethanol beutanol and propanol blends of $25 \%$ proportions, these results in the decrease of the UBHC emissions of CCP when compared to BP. Due to mixing of blends, at high temperatures, Engine will have sufficient amount of oxygen, which mixes with $\mathrm{HC}$ emissions. As a result $\mathrm{HC}$ will split in to $\mathrm{H}$ and $\mathrm{C}$ which mixes with $\mathrm{O}_{2}$ thereby reducing the $\mathrm{HC}$ emissions. When comparing with the $\mathrm{BP}$ and $\mathrm{CCP}$ with the emissions are reduced up to $28 \%-30 \%$.

$>$ The emissions of $\mathrm{CO}$ for various loads, it is found that the $\mathrm{CO}$ emissions are decreased in CCP with $25 \%$ of ethanol blend, when compared to the BP due to complete combustion. At high temperature $\mathrm{C}$ easily combines with $\mathrm{O} 2$ and reduces $\mathrm{CO}$ emission. This results in the reduction of the $\mathrm{CO}$ emissions up to $23 \%-25 \%$, when compared to the BP and CCP of blend ethanol $25 \%$.

\section{Acknowledgment}

The authors are expressing their gratitude to the Department of Mechanical Engineering, Annamacharya Institute of Technology and Sciences (Autonomous), Rajampet, Kadapa Dist, for their constant support and encouragement.

\section{References}

[1]. S.NARASIMHA KUMAR: "experimental investigation of two stroke copper coated spark ignition engine with gasoline and gasohol” international journal of emerging science and engineering (ijese) issn: 2319-6378, volume-2, issue-5, march 2014.

[2]. T.O. WAGNER, D.S. GRAY, B.Y. ZARAH, A.A. KOZINSKI, practicality of alcohols as motor fuel, SAETecnical paper 790429 (1979) 1591-1607.

[3]. MURTHY, P.V.K., NARASIMHA KUMAR, S., MURALI KRISHNA, M.V.S., SESHAGIRI RAO, V.V.R. AND. REDDY, D.N., Aldehyde emissions from two- stroke and four-stroke spark ignition engines with methanol blended gasoline with catalytic converter, International Journal of Eng. Research and Tech., 3(3),793.802 , 2010.

[4]. VIRAL K PANDYA, SHAILESH N CHAUDHARY, BAKUL T PATEL, PARTH D PATEL: "experimental study on the effect of methanol - gasoline, ethanol-gasoline and n- butane gasoline blends on the performance of 2-stroke petrol engine" International Journal of Advances in Engineering \& Technology, Nov 2011.@IJAET ISSN: 22311963 